DOI: $10.17951 / \mathrm{ff} .2018 .36 .2 .19-30$

A N N A LES

UNIVERSITATIS MARIAE CURIE-SKŁODOWSKA

LUBLIN - POLONIA

VOL. XXXVI

SECTIO FF

$2-2018$

\title{
JAKUB OSIŃSKI
}

Uniwersytet Mikołaja Kopernika

ORCID ID: https://orcid.org/0000-0002-4376-3214

\section{Glosa do orfeistów \\ (na marginesie wiersza Rośliny Kazimierza Wierzyńskiego)}

Gloss to Orfeists (About the Poem Rośliny [Plants] by Kazimierz Wierzyński)

Motywy orfickie, mimo że bez trudu można odnaleźć je w powojennych wierszach Kazimierza Wierzyńskiego, bez wątpienia nie należą do tych, które poeta najczęściej eksploatował. Niemniej jednak są przez badaczy często interpretowane i porównywane z utworami innych autorów (np. Czesława Miłosza, Aleksandra Wata, Tadeusza Różewicza czy Józefa Wittlina), co bez wątpienia świadczy o znaczeniu mitu o Orfeuszu w powojennej poezji twórcy Korca maku. Pierwszy wspomnianym motywom przyjrzał się Krzysztof Dybciak (1987), w ślad za nim poszli Jerzy Poradecki (1995) i Agnieszka Rydz (2004), ostatnio zaś temat zainteresował Macieja Jaworskiego (2017). Warto przy tym odnotować, że spośród wymienionych tylko Dybciak i Rydz zajmowali się twórczością Wierzyńskiego szerzej niźli jedynie w kontekście mitu orfickiego. Jednak wszyscy ci interpretatorzy - świadomie bądź nie - pomijają w swoich pracach wiersz zatytułowany Rośliny, pochodzący z tomu Korzec maku (1951). Wiersz wcześniejszy niż przez nich omawiane, a więc przede wszystkim Rozmowa z Orfeuszem z tomu Siedem podków (1954) oraz Słowo do Orfeistów z Tkanki ziemi (1960)ํ. Wiersz, w końcu należy powiedzieć, który warto przypomnieć dlatego, że mit orficki został w nim wykorzystany zupełnie inaczej

1 Należy tu zaznaczyć, że Orfeusz pojawia się jeszcze w innych wierszach poety, które były jednak rzadziej analizowane przez badaczy, np. Orfeusz z Róży wiatrów (1942) czy Argonauci z Korca maku (1951). Z wymienionych interpretatorów najszerzej omówił ten motyw Poradecki. Mimo to - podkreślmy raz jeszcze - tylko wiersz Rośliny nie został choćby wspomniany w żadnym z tych opracowań. 
niż we wspomnianych utworach. Dybciak (1987:60) o Rozmowie z Orfeuszem i Stowie do Orfeistów pisze wszak:

W wierszach Wierzyńskiego ,ja” liryczne mówi o Orfeuszu wprost i od początku, bo już w tytule. Nie mówi natomiast bezpośrednio, iż utwory te są wyznaniem dotyczącym źródeł i sensu poezji, a więc mogłyby - przynajmniej w podtytule - zostać określone jako ars poetica.

Spostrzeżenia Dybciaka nijak mają się do liryku Rośliny, w którym próżno szukać (choćby pośredniej) refleksji nad sztuką poetycką, a - co istotniejsze - o Orfeuszu mowa jest dopiero w ostatnim wersie. Zresztą przywołajmy słowa wiersza:

Jest nas wielka rodzina

Splątana korzeniami,

Czarnooka Zuzanna,

Złocisty Aleksander,

I Trawa z Parnasu;

Brat jest zielony,

Siostry niebieskie

A każda panna

Srebrna $\mathrm{z}$ atłasu.

Jest Pióro Salomona,

Które owocuje perłami,

Jest Kapusta Skunksa

I Orchidea Grzechotnika,

I jest w okularach

I w kaloszach na bagnie

Wypatrująca cudów

W naszem podziemiu

Eurydyka.

Rośniemy w głębinnych praczasach,

Żyjemy w bezczynnych lasach,

Za skórą ziemi rosistej

W magmie mulistej,

W drożdżach korzennych,

Rodzina Ślepych,

Pięknych

I Sennych.

Kolibry pluszczącą chmurą

Nad nami w powietrzu stoją

Trzmiele jedzą nas głodne, 
Pszczoły swatają miodne

I sarny tratują

U wodopoju.

A pod łopianem, pod liściem olbrzymem,

Pod parasolem i baldachimem

Siedzi na tronie złoto-zielony,

Poważny i gruby

Żuk, nasz król, Skarabeusz:

On wszystko słyszy, wszechwiedny,

Koboldy wysyła z pomocą,

Kiedy zakrzyczy nocą

Szukający swej zguby

Orfeusz (Wierzyński, [1959]:476-477)².

Tytułowe rośliny, kolejno przez Wierzyńskiego wymieniane, przywołane zostały za pomocą swoich popularnych, ludowych nazw: „Czarnooka Zuzanna” - tunbergia oskrzydlona, „Złocisty Aleksander” - tojeść kropkowana, „Trawa z Parnasu” - dziewięciornik błotny, „Pióro Salomona” - kokoryczka, „Kapusta Skunksa” - skupnia, „Orchidea Grzechotnika” - tajęża ${ }^{3}$. One też są „my” lirycznym utworu, opowiadają o swoim świecie.

$\mathrm{Z}$ jednej strony można stwierdzić, że poeta uzyskał dzięki temu zabiegowi zamierzony efekt familiarności i pieczołowitości roślinnego świata: „Jest nas wielka rodzina | Splątana korzeniami”. Z drugiej zaś zauważyć należy, że nazwy te ewokują rozmaite skojarzenia związane ze starożytnością. Zuzanna i Salomon są oczywiście postaciami biblijnymi, symbolizującymi odpowiednio cnotę i mądrość. Imię Aleksander przywodzi na myśl Aleksandra Macedońskiego, jednego z najwybitniejszych w historii strategów. Parnas to, rzecz jasna, mityczna siedziba patronującego sztuce Apolla. Skunks i grzechotnik - wywołujące raczej pejoratywne skojarzenia - nie mają co prawda tak narzucających się kulturowych konotacji, jednak ich obecność w wierszu nie wydaje się przypadkowa. Można je uznać za wprowadzające do symbolicznego świata roślin różnorodność i równowagę między tym, co szlachetne a tym, co powszechne (skunks) czy złe i niegodziwe (grzechotnik).

2 Pierwodruk: „Kultura” (Paryż) 1949, nr 16-17, s. 197-198. (W tym samym numerze ukazały się wiersze: Wiatr, O ceratowej wstązce, O moim geniuszu i $O$ naszych kwiatach.) W tomie: Korzec maku, Londyn 1951, s. 95-96. Warto już w tym miejscu odnotować, że pierwodruk wiersza Rośliny różni się w kilku miejscach od późniejszych jego edycji (Korzec maku, Poezje zebrane), czemu poświęcimy uwagę dalej.

3 Za konsultację w tej kwestii dziękuję dr. Dariuszowi Kulusowi z Uniwersytetu Technologiczno-Przyrodniczego w Bydgoszczy. 
Niepostrzeżenie dla czytelnika, ni stąd, ni zowąd w tych „bezczynnych lasach” pojawia się Eurydyka. I choć - zgodnie z przekazem mitologicznym - nie powinno to dziwić, wszak miała ona być leśną nimfą, to jednak wygląd bohaterki lirycznej daleki jest od starożytnych wyobrażeń. Przedstawiona zostaje bowiem „w okularach | I w kaloszach". Mimo że nie pasuje do kreowanego w wierszu obrazu, nie poświęca się jej więcej uwagi; niknie wręcz w ,głębinnych praczasach”. Przypomni o niej dopiero w zakończeniu Orfeusz, ,[k]iedy zakrzyczy nocą | Szukający swej zguby”.

I my przypomnijmy: Orfeusz poszukiwał Eurydyki, gdy zmarła ukąszona przez węża. O tym jednak w wierszu nie ma mowy ${ }^{4}$. Żona poety została opisana jako „Wypatrująca cudów | W naszem podziemiu”. Jest to dla interpretacji utworu fragment kluczowy, wszak tytułowe rośliny dopowiadają (przywołajmy te słowa raz jeszcze):

Rośniemy w głębinnych praczasach,

Żyjemy w bezczynnych lasach,

Za skórą ziemi rosistej

$\mathrm{W}$ magmie mulistej,

W drożdżach korzennych.

Znane z mitologii zejście Orfeusza do podziemi, zdarzenie najważniejsze dla reinterpretacji mitu orfickiego, zostaje zatem przez Wierzyńskiego przetransponowane. W interesującym nas wierszu nie ma bowiem w ogóle mowy o śmierci Eurydyki czy przemierzaniu Hadesu przez Orfeusza. Podziemia, zaświaty to nie królestwo śmierci, lecz królestwo roślin. W końcu też sam Orfeusz niewiele ma wspólnego z mitycznym poetą, śpiewającym przy akompaniamencie harfy, lutni czy liry. Jedyny dźwięk, który z siebie wydobywa, to krzyk - może jeszcze nawoływania, może już rozpaczy.

Nie da się zatem ukryć, że utwór jest daleki od innych wierszy Wierzyńskiego $\mathrm{z}$ tego okresu.

Korzec maku - jak słusznie zauważa Jolanta Dudek (1975:22) - to [...] próba odzyskania dawnej, pogodnej i optymistycznej postawy wobec otaczającego świata i codziennego życia. Postawa ta do końca twórczości Wierzyńskiego będzie walczyła z tragizmem jawnym lub ukrytym.

4 Warto zwrócić uwagę na bardzo ciekawe i charakterystyczne dla poezji Wierzyńskiego z tego okresu nieregularne rymy. „Eurydyka” (w. 18) rymuje się bowiem z „Grzechotnika” (w. 13), co może - choć nie musi - być ,zaszyfrowanym” nawiązaniem do mitologicznego przekazu o śmierci żony Orfeusza. Podobnie zresztą „Orfeusz” (w. 41) rymuje się ze „Skarabeusz” (w. 36), co - jeśli uwzględnimy starożytne wierzenia - może wiązać się z powrotem poety z zaświatów (skarabeusz był symbolem ponownego narodzenia). 
W Roślinach tragizm bezspornie rzeczoną walkę jeszcze wygrywa. Dramat, którego możemy się tylko domyślać, przesłania wszelką refleksję nad sztuką, typową dla wiersza wykorzystującego motywy orfickie. Wobec tego omawiany utwór poprzedza słynne zawołanie z Rozmowy z Orfeuszem: „Świat nie ma sensu, | Sens ma sztuka” (Wierzyński, [1959]:555); jest wcześniejszym stadium refleksji Wierzyńskiego nad miejscem oraz rolą sztuki i artysty w powojennym świecie. Innymi słowy: sztuka nie zyskała jeszcze dla poety sensu, kiedy już świat zdążył ów sens utracić.

Zdaje się właśnie, że kontekst historyczny, a więc tragedia wojenna, leży u źródeł przesłania zawartego w omawianym utworze. Poetyckie poszukiwania Wierzyńskiego, co do czego historycy literatury nie mają wątpliwości, zrodziły się bowiem z przekonania o ocalającej wartości sztuki i konieczności jej dalszego trwania mimo tragedii, jaką była wojna ze wszystkimi swoimi konsekwencjami. Na tak silnie związane z kontekstem historycznym odczytanie pozwala zresztą „współczesny” wygląd Eurydyki, oddalający nas od uniwersalizującej interpretacji.

Przestrojenie poetyckiej lutni - przypomina jednak Agnieszka Rydz (2004:150) - z rzewno-wojennej na chwalącą urodę życia [...] przysporzyło autorowi Korca maku zwolenników wśród nowej generacji czytających, jednak trzeba pamiętać, że część tradycyjnie zorientowanej emigracji zarzucała mu, iż „wymienił żołnierskiego orzełka na wiewiórkę”.

Owa symboliczna „wiewiórka”, a więc zwrócenie się poety ku „mowie i ziemi”, poczytywane mu było niekiedy - co nie powinno dziwić - jako wyraz eskapizmu bądź awangardowej ekwiwalentyzacji. Z dzisiejszej perspektywy możemy jednak orzec, że powojenna poezja Wierzyńskiego naznaczona jest nie oddalaniem, lecz zbliżaniem się do świata, poszukiwaniem w nim miejsca, próbą uchwycenia jego ogromu i złożoności, przeszłości i przyszłości. Dotyczy to również omawianego utworu. Świat roślin nie ma wcale przesłonić świata ludzkiego czy nawet go symbolizować - jest wszak odrębnym i równoległym, choć przenikającym się z innymi światami, odwiecznym porządkiem - światem w świecie, tak samo jak świat zwierząt:

Kolibry pluszczącą chmurą

Nad nami w powietrzu stoją

Trzmiele jedzą nas głodne,

Pszczoły swatają miodne

I sarny tratują

U wodopoju.

I w końcu też tak samo jak świat ludzi - tu reprezentowany przez Orfeusza i Eurydykę. 
Królestwo roślin, wzbudzające w Eurydyce zachwyt i podziw, jest Orfeuszowi przyjazne - król Skarabeusz wysyła mu przecież na pomoc koboldy, leśne skrzaty. Nietrudno zauważyć, jak ów świat różni się od świata ludzkiego - jest piękny, spokojny, harmonijny („Rodzina Ślepych, | Pięknych | I Sennych”). Doskonale oddaje to jego zróżnicowana i szlachetna kolorystyka, którą posłużył się poeta. Oprócz roślinnej zieleni pełno w nim barw złota, srebra i pereł. Można wręcz wysnuć refleksję, że w to, czego ludzie tak pożądają, a więc metale szlachetne, perły czy atłasy, królestwo roślin obfituje, nie wzbudzając w nikim i niczym chciwości. Jest to świat cichy, w przeciwieństwie do ludzkiego; jedynie gdzieś w oddali, na niebie „[k]olibry pluszczącą chmurą | Nad nami w powietrzu stoją”.

Dopiero krzyk bohatera lirycznego burzy porządek i przerywa ciszę. Do królestwa roślin wtargnął człowiek i jego świat - „Orfeuszowy świat” z wiersza Muzy. Rydz (2004:9) pisze:

W Muzach - liryku otwierającym pierwszy powojenny zbiór wierszy - (który możemy uznać za utwór programowy dla odnowicielskiej poezji Kazimierza Wierzyńskiego) zaprezentował on swoją osobę jako „lutnistę | Ciemnego czasu i losu” [...], rzeczywistość zaś po kataklizmie drugiej wojny światowej przedstawił w metaforze „Orfeuszowy świat”. Odwołanie do mitu nie jest tutaj formą indywidualnego eskapizmu ani „upiększania” brutalnych realiów życia, tylko sposobem osiągania dystansu. „Orfeuszowy świat” prowadzi również w obszar sztuki, przywodzi myśl o jej posłannictwie, mocy oraz ograniczeniach. Nade wszystko wyraża niezachwianą, silną wiarę w katarktyczną funkcję słowa.

\section{Podobne przekonanie wyraża Wojciech Ligęza (2014:21):}

Restytucja mowy poetyckiej ma służyć zapominaniu o traumie. Gniew i zło, dowodzi Wierzyński, nie sprzyjają pieśni, gdyż „Nie ma śpiewu | z czeluści otwartej” [...]. Postać śpiewaka i poety, syna Kaliope (niekiedy podstawiano w to miejsce Polihymnię) - Orfeusz - jednoczy tendencje późnej liryki Wierzyńskiego, łączy jasną (ocalającą) stronę kultury z ciemnymi obszarami człowieczego losu.

Zanim jednak nadeszło ocalenie, a ów „Orfeuszowy świat” poprowadził poetę ku sztuce, w jego twórczości obecny był jedynie dopiero co miniony kataklizm - wojna, śmierć najbliższych, wychodźstwo i emigracja. Jego echa, echa krzyku Orfeusza pobrzmiewają jeszcze w wierszu Piąta pora roku z tomu Tkanka ziemi:

I rzekł mój ojciec do matki mojej,

Dym odpędzając pod koniec wojny:

„Nie bój się, wszystko się tak uspokoi

W śmierci wieczyście spokojnej” (Wierzyński, 1960:9).

Pojawia się w tym utworze śmierć, a więc dobrze znane dokończenie historii Orfeusza i Eurydyki, nieobecne jednak w Roślinach. Piąa pora roku to 
wszak - zgodnie z ustaleniami Marii Dłuskiej (1972:129-130; zob. także Dudek, 1975:84) - wiersz o „legendzie wieczności”, ergo nieśmiertelności, i to dwojako pojmowanej: po pierwsze, jako przynależność człowieka do świata cyklicznej, odradzającej się natury, po drugie zaś - horacjańsko, jako sztuka. Choć perspektywę taką Wierzyński przyjął dopiero po kilku latach, już w interesującym nas tu liryku możemy wskazać na pewne jej oznaki: zbliżenie do natury oraz, przede wszystkim, sięgnięcie po motyw Orfeusza, par excellence potwierdzający nieprzemijalność sztuki.

$\mathrm{Na}$ drodze rozwoju poetyckiej refleksji Wierzyńskiego pomiędzy Roślinami a Piąta pora roku jest w końcu, jak się zdaje, jeszcze jeden bardzo ważny utwór - Mowa i ziemia. Dłuska (1972:136) pisała, że ,[t]o, co łączy obydwa utwory [Mowę i ziemię oraz Piąta porę roku - przyp. J.O.], to naczelna idea, koncepcja pierwotnego i niezniszczalnego związku człowieka i jego słowa, jego poezji, z ziemią, na której się urodził i wyrósł".

Idea ta co prawda w Roślinach dopiero „kiełkuje”, jednak już chronologiczne zestawienie tych trzech utworów pozwala z łatwością dostrzec, jak w interesującym nas wierszu Orfeusz zbliża się do ziemi, do natury; jak to od niej zaczynają się jego poszukiwania, które ostatecznie doprowadzą Wierzyńskiego do tytułowego „źródłosłowu” z wiersza opublikowanego w tomie Siedem podków:

Jakże ja was odmłodzę,

Zacznę na nowo i zmienię,

Rozdrzewię i zazielenię,

Ja was rozszumię i rozkołyszę... (Wierzyński, [1959]:558).

Jeśli powtórzyć za Dłuską (1972:138), że „[w] Mowie i ziemi Wierzyński staje się poetą, [a - przyp. J.O.] w Piątej porze roku jest nim z natury", można dopowiedzieć, iż w Roślinach, przytłoczony okrucieństwem świata, jeszcze w ogóle nie ma takich ambicji. Poetą nie jest, ale stanie się nim, co zapowiada właśnie obecność Orfeusza. Jego krzyk z czasem przerodzi się w śpiew.

I to nie nastąpi jednak bez przeszkód, czego świadectwa odnaleźć możemy $\mathrm{w}$ innych utworach Wierzyńskiego z tego okresu, np. Pracowni poety z Korca maku. Pojawia się w tym wierszu platońska rozterka dotycząca sztuki jako naśladownictwa (mimesis), nijak mającego się do piękna i doskonałości natury, której nie sposób uchwycić ani odwzorować (Andres, 1997:149). Jasne staje się więc, dlaczego w Roślinach to właśnie tytułowi bohaterowie są ,my” lirycznym, dlaczego to oni, a nie poeta - Orfeusz - opowiadają o swoim świecie.

Powróćmy tu jeszcze do motywu śmierci, jako że jego znaczenie jest tak w Roślinach, jak i Mowie i ziemi oraz Piatej porze roku niebagatelne. Pisała dalej Dłuska: 
W Mowie i ziemi z nią [śmiercią - przyp. J.O.] następuje koniec. Nie ma dalszego ciągu. Po latach ukazuje się jednak Piąta pora roku. Jak gdyby kontynuacja tamtego wiersza. Jakby replika samemu sobie i własna sobie samemu odpowiedź na tragizm oddalenia i śmierci. Jeśli Mowa i ziemia to beznadziejny los człowieka, który wszystkimi korzeniami swoimi i swojego słowa, swojej poezji wrośnięty był w ziemię rodzinną, a potem wydarty z niej przez kataklizm; który stwierdza „że nie ma wyjścia”; którego życie stało się wędrówką w hipnotycznym półśnie, bez innej perspektywy niż dojście tam, gdzie „świat się kończy urwiskiem” [...] - to Piąta pora roku otwiera perspektywę poza i ponad doczesność wędrówki (Dłuska, 1972:137).

W Roślinach, jak już ustaliliśmy, śmierci jeszcze nie ma, a przynajmniej pozostaje ona nienazwana. Historia Orfeusza i Eurydyki nie kończy się w dobrze nam znany sposób, lecz urywa ją krzyk poety. Kiedy po kilku latach śmierć pojawia się już explicite w Mowie i ziemi, zdaje się ostateczna, wszak w uniwersum wiersza czas zamyka się w doczesności. Dopiero w Piątej porze roku śmierć zostaje przezwyciężona, następuje otwarcie na to, co poza „tu i teraz”.

Nie byłoby to jednak możliwe bez dostrzeżenia „,praczasu”, o którym Wierzyński wspomina właśnie w Roślinach. Zanim jednak przejdziemy do analizy tego pojęcia, poczyńmy pewne ustalenia tekstologiczne. Dwa wersy (19-20), w których mowa o „praczasie” są bowiem inne w pierwodruku niż w późniejszych wydaniach:

\begin{tabular}{c|l|l} 
Wers & „Kultura” (1949) & Korzec maku (1951), Poezje zebrane (1959) \\
\hline 19 & Rośniemy w głębinnych lasach & Rośniemy w głębinnych praczasach \\
\hline 20 & Żyjemy w bezczynnych czasach & Żyjemy w bezczynnych lasach
\end{tabular}

Wprowadzone przez poetę zmiany mają dwojaki charakter: wersyfikacyjny i składniowy. Wersyfikacyjny, ponieważ pierwotnie oba wersy (a także wers kolejny - 21) miały taką samą budowę: były to ośmiozgłoskowce składające się z dwu amfibrachów i jednego trocheju:

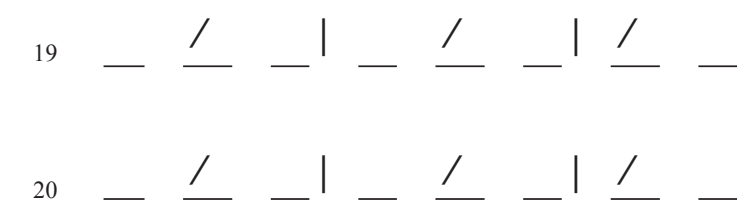

Po zmianach wers 19 stał się dziewięciozgłoskowy: 


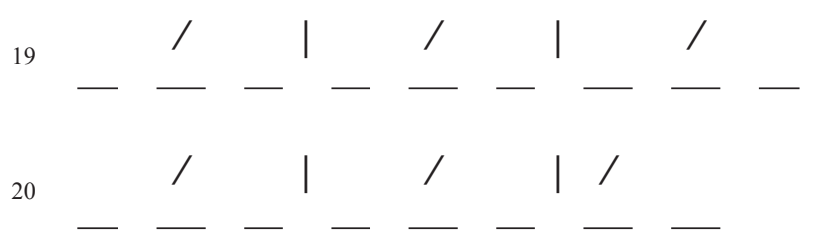

Zmiany w tak ,regularnie nieregularnym” wierszu Wierzyńskiego nie mogły być wynikiem przypadku. Tym bardziej że trzecia strofa (w. 19-26), którą rozpoczynają przytoczone wersy, jest najbardziej regularna w całym utworze ${ }^{5}$.

Jeśli mowa o zmianach na poziomie składniowym, to dotyczą one związków wyrazowych: „głębinne lasy”/,głębinne (pra)czasy” oraz „bezczynne czasy”/,bezczynne lasy”. Choć nie ma wątpliwości, że przymiotniki „głębinny” i „,bezczynny” znaczą zupełnie co innego, zarówno syntaktycznie, jak i semantycznie poprawne są ich połączenia z rzeczownikami „las” oraz „czas”.

"Głębinny” to przymiotnik pochodzącym od rzeczownika „głębina”, który ma wiele znaczeń, występuje m.in. w kontekstach: „głębiny morskie”, „głębina nieba” czy „głębina ducha”. Wszystkie one odnoszą się jednak do tajemniczości i nieosiągalności dla człowieka. „Głębinne lasy” z pierwotnej wersji utworu byłyby zatem przestrzenią człowiekowi obcą, przezeń niepoznaną, być może nawet dla niego niebezpieczną. „Głębinne (pra)czasy” to natomiast dzieje dawne i mgliste, do których nie sięga jakakolwiek ludzka forma pamięci.

„Bezczynny” thumaczyć można z kolei jako bierny i spokojny. „Bezczynny czas" oznacza więc mityczny czas stagnacji, czas, który nie przynosi żadnych zmian. Tak samo nic nie zmienia się w „bezczynnym lesie”, który po prostu trwa i jest pasywny, przez co najwyżej poddaje się wpływom zewnętrznym.

Reasumując te semantyczne rozważania, można zatem powiedzieć, że pierwotnie świat roślin został przedstawiony w wierszu jako odizolowany od człowieka, całkowicie mu nieznany, być może skrywający przed nim jakąś tajemnicę, ale i będący całkowitym przeciwieństwem świata ludzkiego w czasach „czynu” (np. zbrojnego), w którym tyle się dzieje. W późniejszych wydaniach nie świat roślin jest człowiekowi obcy i nieznany, lecz czas, który w nim trwa - mityczny „praczas”.

Warto w tym miejscu odnotować jeszcze jedną zmianę

5 Nie ma tu miejsca na szczegółową analizę wersyfikacyjną omawianego wiersza. Pietyzmu Wierzyńskiego w tym zakresie na przykładzie innych utworów dowiodła już zresztą Dłuska (1972).

6 Inne, mało istotne różnice to:

\begin{tabular}{c|l|l} 
Wers & „Kultura” (1949) & Korzec maku (1951), Poezje zebrane (1959) \\
\hline 17 & W naszym podziemiu & W naszem podziemiu \\
\hline 18 & Euredyka & Eurydyka \\
\hline 31 & Przy wodopoju. & U wodopoju.
\end{tabular}

Poza tym w pierwodruku wyodrębniono graficznie trzy ostatnie wersy jako osobną strofę. 


\begin{tabular}{c|l|l} 
Wers & „Kultura” (1949) & Korzec maku (1951), Poezje zebrane (1959) \\
\hline 1 & Jest nas wielka rodzina & Jest nas wielka rodzina \\
2 & Związana korzeniami & Splątana korzeniami
\end{tabular}

Ta z pozoru niewielka, stylistyczna jak by się zdawało poprawka, może mieć w kontekście tego, co powiedzieliśmy już o „praczasie” niemałe znaczenie. Otóż „Związanie” zawsze narzuca jakiś ład, porządek, w przeciwieństwie do „splątania”, które tego ładu jest pozbawione. Wyrażenie „Rodzina | Splątana korzeniami” odsyła nas zatem do mitycznych początków świata, który wyłonił się - wedle przekazów starożytnych $-\mathrm{z}$ chaosu.

Po raz kolejny przywołajmy tu słowa Dłuskiej (1972:126):

Centralnym zagadnieniem Piątej pory roku jest czas. Wskazuje na to już tytuł wiersza, metafora odnosząca się do faz życia i więcej niż do nich, bo do wieczności i śmierci. Czas wkracza jako ruch i zmienność, następstwo ,pór roku” - pór życia, jako przeszłość i przyszłość - ale zarazem jako wieczność, czyli niezmienność, jednocześnie i nieruchomość trwania w nieskończoności.

Czas w Piatej porze roku, jak się zdaje, jest czasem w prostej linii wywiedzionym właśnie z „praczasu” - „przed-czasu”, a więc tego, co poza teraźniejszością, i to zarówno poza „tu i teraz”, jak i poza „długim trwaniem”. Czas był wszak zawsze, nie ma początku ani końca. A jednak Wierzyński, na mocy licentia poetica, rezygnuje z nadawania mu tej przyrodzonej, stricte fizycznej własności, wskazując, że i nieskończony czas miał swojego następcę. Ten bez mała paradoksalny zabieg uznać można za próbę dowiedzenia, że nie ma, bo i nie może być, ruchu i zmienności, które dokonują się w czasie, bez stateczności i niezmienności będących domeną ,praczasu". Idąc dalej, trzeba w końcu rzec, że śmierć ma zawsze miejsce w jakimś czasie, zaś wieczność i nieśmiertelność, „mowa i ziemia” - w „,praczasie”.

„Praczas” jest skryty za „skórą ziemi rosistej”. „Poetycki mit ziemi” - który narodził się już w przedwojennych utworach Wierzyńskiego, szczególną zaś rolę zaczął odgrywać w wierszach z okresu wojennego - zdaje się doskonałym potwierdzeniem przedstawionych wyżej hipotez interpretacyjnych. Przywołajmy tu choćby wezwanie otwierające wiersz pt. Ewangelia z tomu Krzyże i miecze (1946):

Ulecz nas, ziemio trwała, ziemio sama w sobie,

Świecie nasz teraźniejszy i przyszły nasz w grobie (Wierzyński, [1959]:386).

Słowa te komentuje Zbigniew Andres (1997:107):

Związek człowieka z ziemią jest nierozerwalny. W wierszu Ewangelia znaleźć można swoistą, maksymalnie skondensowaną wersję uniwersalnego motywu ziemi-grobu i ziemi-kolebki, a więc matki, symbolicznej i czującej Tellus Mater. [...] 
Człowiek jest owocem ziemi, ziarnem zasianym w glebie. Ziemia regeneruje jego siły i udziela mu daru nowego życia.

Do tego związku homo - humus nawiązuje poeta także w Roślinach, choć już nie tak bezpośrednio. Wszak to właśnie ,podziemia” podziwia Eurydyka; to „pod łopianem, pod liściem olbrzymem" rezyduje król żuk, który śle Orfeuszowi pomoc.

Między wierszem Rośliny a Mowa i ziemiq oraz Piata pora roku jest jeszcze jedna, zasadnicza różnica, także stanowiąca świadectwo ewolucji poetyckiej Wierzyńskiego. Otóż wymienione przezeń rośliny nie występują na ziemi karpackiej, w „małej ojczyźnie” poety, którą ten uczynił przestrzenią swoich późniejszych utworów. Może to więc świadczyć o tym, że nostalgia przyszła dopiero z czasem, kiedy spotęgowaniu uległa tęsknota za opuszczonym - jak się okazało - na zawsze „krajem lat dziecinnych”.

W kontekście biograficznym przedstawione w wierszu silne rodzinne związki roślin, ich - pojęte ex definitione i metaforycznie - zakorzenienia także zyskują dodatkowe znaczenie. Zwiększają bowiem rozziew między idealizowanym arkadyjskim światem roślin a światem ludzi, światem „Orfeusza w piekle XX wieku”. Trzeba w tym miejscu przypomnieć, że dla Wierzyńskiego wojna wiązała się nie tylko z tułaczką po świecie, ale i z utratą wielu bliskich członków rodziny, m.in. rodziców i rodzeństwa, których pamięci poeta poświęcił Krzyże i miecze (zob. Osiński, 2014). Wystarczy powrócić do zestawienia Roślin z Piąta porą roku, by jasne stało się, że w późniejszym wierszu to właśnie rodzice pełnią rolę przewodników poety niczym - na co wskazywała Dłuska (1972:129-130) - duchy zmarłych dla Dantego, kiedy ten przemierzał piekło. „,[W]ielka rodzina” jest obiektem jego aktualnych tęsknot.

Wszystko, o czym w tym szkicu powiedziano, zdaje się dostatecznie ukazywać rangę omówionego utworu w powojennej poezji Wierzyńskiego. Wiersz stanowi potwierdzenie rozwoju twórczości będące świadectwem artystycznych poszukiwań, wkraczania w świat natury - jeden z „obszarów ocalenia” (Ligęza, 1985). W końcu też Rośliny dowodzą, że często i wielorako interpretowane przez badaczy motywy orfickie są u Wierzyńskiego różnie wykorzystywane, a w konsekwencji nie stanowią żadnego poetyckiego credo, którym można by objąć całą poezję tego autora.

\section{BIBLIOGRAFIA PODMIOTOWA}

Wierzyński, K. (1949). Rośliny. Kultura (Paryż), 16/17, s. 197-198.

Wierzyński, K. (1951). Korzec maku. Londyn: Katolicki Ośrodek Wydawniczy Veritas.

Wierzyński, K. ([1959]). Poezje zebrane. Londyn-Nowy Jork: Wydawnictwo „Wiadomości” - Polski Instytut Naukowy.

Wierzyński, K. (1960). Tkanka ziemi. Paryż: Instytut Literacki. 


\title{
BIBLIOGRAFIA PRZEDMIOTOWA
}

Andres, Z. (1997). Kazimierz Wierzyński. Szkice o twórczości literackiej. Rzeszów: Wydawnictwo Wyższej Szkoły Pedagogicznej.

Dłuska, M. (1972). Studia i rozprawy, 3. Kraków: Wydawnictwo Literackie.

Dudek, J. (1975). Liryka Kazimierza Wierzyńskiego z lat 1951-1969. Wrocław: Zakład Narodowy im. Ossolińskich.

Dybciak, K. (1987). Istnienie jest śpiewem i rytmem. Współczesny orficyzm. W Drodze, 9, s. 60-70. Jaworski, M. (2017). Nowoczesny Orfeusz. Interpretacja mitu w literaturze polskiej XX-XXI wieku. Warszawa: Wydawnictwo IBL PAN.

Ligęza, W. (2014). Muzyka w wierszach Kazimierza Wierzyńskiego. Zeszyty Naukowe Towarzystwa Doktorantów UJ. Nauki Humanistyczne, 5, s. 13-27.

Ligęza, W. (1985). Obszary ocalenia. Natura, słowo i kultura w późnej liryce Kazimierza Wierzyńskiego. W: T. Bujnicki, W. Wyskiel (red.), Pisarz na obczyźnie (s. 169-183). Wrocław: Zakład Narodowy im. Ossolińskich.

Osiński, J. (2014). „Skowyt nadczłowieczy spod ziemi dalekiej”. Powstanie warszawskie w poezji Kazimierza Wierzyńskiego. Polonistyka, 9, s. 16-18.

Poradecki, J. (1995). Orfeusz poetów dwudziestego wieku. Łódź: Wydawnictwo Biblioteka.

Rydz, A. (2004). , Świat nie ma sensu, sens ma sztuka”. O powojennej poezji Kazimierza Wierzyńskiego. Warszawa: Semper.

\begin{abstract}
ABSTRAKT
Artykuł został poświęcony interpretacji wiersza Kazimierza Wierzyńskiego (1894-1969) pt. Rośliny z tomu Korzec maku (1951). Autor starał się ukazać inny sposób wykorzystania przez poetę mitu o Orfeuszu i Eurydyce niż te dotychczas omówione przez badaczy. W tym celu przeprowadził dokładną analizę utworu, w której uwzględnił budowę wiersza oraz konteksty biograficzne, historyczne i literackie. Rozważania potwierdziły, że wśród utworów Wierzyńskiego zawierających motywy orfickie Rośliny zajmują miejsce osobne, a przy tym odzwierciedlają ważne stadium rozwoju powojennej twórczości poetyckiej tego autora.
\end{abstract}

Słowa klucze: Kazimierz Wierzyński, Orfeusz, Eurydyka

\section{ABSTRACT}

The article is devoted to the poem Rośliny [Plants] from the volume of poems Korzec maku [The Poppy Seed Flower] (1951) by Kazimierz Wierzyński (1894-1969). In this poem, the author tries to present a new way of using the motive of Orpheus and Eurydice. He analyzes the poem and takes into account its structure and biographical, historical and literary contexts. These analyses confirmed that among the works by Wierzyński, in which the author refers to Orpheus and Eurydice, the poem has its own place and, at the same time, it reflects an important stage in the development of post-war poetry of the author.

Keywords: Kazimierz Wierzyński, Orpheus, Eurydice 